\title{
A CONTRIBUTION TO THE INVESTIGATION OF THE HOLOCENE HISTORY OF THE BEECH IN THE EASTERN NETHERLANDS
}

\author{
A. G. H. DANIELS \\ (Botanical Museum and Herbarium, Utrecht)
}

(received September 10th, 1963)

\begin{abstract}
To study the immigration and spreading of the beech (Fagus sylvatica L.) in the Netherlands during the young Holocene, three peat bogs were palynologically investigated in the eastern Netherlands and in the adjacent German area. For this purpose peat samples have been collected in the Korenburgerveen near Winterswijk, in a peat bog near Burlo (Germany) and in the Aamsveen south-east of Enschede. The analysis of the peat-samples proved, that extensive beech-forests existed in subatlantic times in the subcentreuropean flora district of the Netherlands. This is shown in the comparatively high Fagus-percentages in the pollendiagrams.
\end{abstract}

\section{GeOGRAPHY}

The recent area of Fagus sylvatica stretches from South-Sweden and Norway into northern Spain and towards the east into the Balkans. In the west, the beech is (perhaps) only spontaneous in the south-east of England as far as Dorset, Brecon and Cambridge. In Ireland the beech is absent. In Scandinavia the most northern locality where Fagus still occurs is near Bergen (Norway). This area, however, is separated from the main area and it remains to be seen whether Fagus has arrived here by natural way (FAEGRI, 1954). In Norway the beech is also present along the coast between Oslo and Kristiansand and along the east coast of the Oslofjord. In Sweden it occurs along the west coast and in the south Swedish lowland south of the 59th degree of latitude. In Denmark the beech is present in the whole country except on Bornholm. Here the beech has been indigenous according to MIKKELSEN (1963), with a maximum from subboreal till historical times, when it was extirpated almost completely. Along the Baltic the beech reaches till Gdansk (Danzig). From here the border of the area goes in south-eastern direction to the River Dnjestr. On the Crimea and in the Caucasus, too, Fagus sylvatica is found; further in north Iran in the provinces of Gilan and Mazanderan and in the northern part of Asia Minor. In the Balkans it reaches till Thracia, Macedonia and Thessalia, but it is absent on the Peloponnesos. In Italy the beech occurs in the Alps, the Apennines and on the Etna. Also in Corsica the beech is found in the mountains. It is the same in northern and central Spain (Pyrenees, Castilia and Gallicia). In France the beech is rare in the lowland of the southwest and in the lowest parts of the Mediterranean area, further it 
is common. In Central Europe Fagus is by no means equally distributed (RUBNER, 1925). It was and is still dominating in the south German Alps and the moraine area, in the Württemberg-Bavarian Jura area, in the Paltish-Lotharingian mountains, in the west German mountains between Zeits-Harz-Deistermountains-Teutoburger-forest and Spessart-Odenwald, in the fringe area of the western Baltic with the Pommern Plain, eastern Sleswick and eastern Jutland. The beech is rather rare in northern Germany south of the line Havel-Spree. In South Central-Europe the beech is found in the Erz mountains, Riesenmountains, Fichtelmountains, further in the Bavarian forest, Bavarian Alps, Tiroler Alps, Oetstaler Alps, Vosges, Black Forest, in the Berner Alps and in the eastern Central Alps. In the Netherlands and Belgium the beech is not spontaneous now in the polder area, but it has been planted there to a large extent. In the east of the Netherlands and South-Limburg there are yet remnants of rather luxuriant deciduous forests, in which the beech takes up an important place too. Pollendiagrams of peatbogs from these areas show clearly, that the Netherlands too, at least in these areas, have had rather extensive beech forests.

For the first time Fagus sylvatica was common in Europe in the Pliocene (JoNker, 1963). In the older pleistocene flora of western and central Europe Fagus is usually not present. Apart from some sporadic finds during interstadial phases of the last glaciation, Fagus reappeared again during the Holocene, also in the Netherlands. On account of this behaviour of the beech Jonker supposes that the species had a refuge during the Ice-age and from this Fagus spread again. This refuge may be localized somewhere in the Balkans as is generally accepted at present. Jonker reports data, from which it may be concluded that the refuge was situated around the Adriatic.

\section{ECOLOGY}

The beech occurs both in the mountains and in the lowlands. South of the Alps we find it only in the mountains, north of the Alps in the lowlands too, but there preferably in hilly districts. In the north the beech occurs on lower levels than in the south: Etna $2000 \mathrm{~m}$, Apennines $1800 \mathrm{~m}-1900 \mathrm{~m}$, Alps till $\pm 1500 \mathrm{~m}$, Erzmountains $\pm 850 \mathrm{~m}$, Harz $250 \mathrm{~m}$ on an average, the Baltic coast $0 \mathrm{~m}$. In the mountains the beech zone develops only above the oak forests. Especially in the Mediterranean and western European mountains the beech forests often form the timberline. Therefore we must consider the beech, according to its present area of distribution, a Central European tree and also a Mediterranean mountain tree, of the temperate mountain climate (Firias, 1949). With the increase of the altitude of the mountain ridges the circumstances become more continental. This mostly implies extreme climatological conditions, against which the beech is less resistant than fir and spruce for example, so that we perceive that the timberline of these trees comes higher (RUBNER, 1934). 
The beech is present especially on rich soil. The Fagetalia here occur; Acereto-Fagetalia (in the mountains) and Querceto-Fagetalia (in the lowland). But on less rich soil too, the Fagus associations can form a climax; Luzulo-Fagetum (in the mountains) and the Fageto-Quercetum (Querceto-Betuletum). The associations in the Netherlands, in which the beech can take an important part, are: the Fraxino-Ulmetum, the Querceto-Carpinetum and the Querceto-Betuletum (Fageto-Quercetum). The Fraxino-Ulmetum occurs on limy, moist sandy soil. It is a rare association in the Netherlands. The beech does not establish easily in it on account of the undergrowth. Because the tree takes root only superficially, it falls over rather soon. Dorng (1962) calls the Querceto-Carpinetum (Querco-Carpinetum) a forest association of rich soil with well developed profile ("Gray-brown podzolic" of Rendzina). The association is absent on the holocene soil, so in the west of the Netherlands. The forest in the east of the Netherlands, in which the peat bogs examined by us, lie, can be classed in the Querceto-Carpinetum. The Carpinion is very rich floristically, but the Dutch Querceto-Carpinetum is an association relatively poor in species. In the $Q . C$. the oak mostly dominates, but the beech too can take an important place in it, though in the Netherlands this is not the case anymore (DoING, 1962). That the oak dominates here, is problably a result of secondary factors, such as human influence. If one leaves the Querceto-Carpinetum alone, there is not much rejuvenation of Quercus.

Then the beech nearly always wins in competition with the oak. Yet the beech is at a disadvantage in the present circumstances, because it does not bud very well and cannot stand any pruning. Besides Fagus only gives viable seeds when it is $60-80$ years old. These and other circumstances are the cause, that also on otherwise good soil only few beeches occur. Originally it was supposed that Fagus was not present in the Querceto-Betuletum, but as it appeared in Westphalia, the beech can be important here too. Though in the Netherlands, the Querceto-Betuletum was replaced by Calluna heath almost everywhere, it yet covers the largest area of all the forest-associations (DoING, 1962). When the climax situation appears, Calluna, Betula and other tree species disappear. Then Quercus and Fagus will dominate (Fageto-Quercetum).

\section{Discussion of THE POLlendiagrams}

\section{The Korenburgerveen}

The Korenburgerveen is situated near Winterswijk in the southeast of the province of Gelderland. The peatbog owns its name from a "Koolburg", derived from "Kolenbranden" (= charcoalburning) (Jonker, 1963). It is property of "de Vereniging tot Behoud van Natuurmonumenten in Nederland" (Society for the preservation of nature reserves in the Netherlands), which gave us kind permission to take samples. The peat was already palynologicaily investigated by TEN HOUTEN (1935). 


\section{Pollenanalytical investigation (diagram 1)}

In the history of the forest of the Korenburgerveen environment 5 periods are to be recognized with the help of the diagram:

1. A Pinus-Betula period $(340 \mathrm{~cm}-325 \mathrm{~cm})$. Pinus and Betula reach values of $\pm 60 \%$ here. This means, according to the zonation according to Overbeck and Schneider that this is the Praeboreal (V). Corylus is present already, but in low percentages.

2. A Pinus period $(325 \mathrm{~cm}-297 \mathrm{~cm})$. Pinus dominates $(60 \%)$. Betula decreases sharply. Corylus increases. Ulmus and Quercus appear, but Tilia is still absent. This is the beginning of the Boreal (O. \& S. VI). Zone VII of O. \& S., which is characterized by a maximum of Corylus, is not present here. Towards the end of the Boreal, Pinus decreases, while Alnus sharply increases. The Atlanticum begins, where the Pinus and Alnus curves meet in the diagram $(290 \mathrm{~cm})$.

3. During the Atlanticum $(290 \mathrm{~cm}-237 \mathrm{~cm})$ the percentage of Alnus is very high (till $92.5 \%$ ). First Pinus is high too, but it goes back towards the end of this period. Betula drops below $5 \%$. Further the high percentage of Tilia is striking.

4. Subboreal (IX) $237 \mathrm{~cm}-165 \mathrm{~cm}$. Corylus increases, Alnus decreases but remains relatively high. After Corylus Quercus occurs most: i.e. mixed oak forests. Tilia and Ulmus decrease. Fagus appears and even shows a continuous curve at the end of this period. In the diagram Fraxinus appears here for the first time.

5. At $140 \mathrm{~cm}$ Fagus is on the increase. Corylus has had his maximum and decreases. This is the beginning of the Subatlanticum (O. \& S. $\mathrm{X}, \mathrm{XI}$ and XII). Tilia does not show a continuous curve anymore.

\section{Fagus}

The increase of the percentage of Fagus starts at a depth of $140 \mathrm{~cm}$. After this the value increases gradually up to $25 \%$. The remarkable thing in the Fagus curve is, that clear maxima and minima are to be noticed. Persch (1950) had something like it in his diagram of the Hohe Venn. He distinguished even 4 maxima in the Fagus curve $\left(F_{1}, F_{2}, F_{3}\right.$ and $\left.F_{4}\right)$. Slotвoom (1963) too has 3 or 4 Fagus maxima in some diagrams of peatbogs in Luxemburg. In the Korenburgerveen 3 Fagus maxima are to be observed in the Subatlanticum, viz. $F_{1} 127 \mathrm{~cm}, F_{2} 90 \mathrm{~cm}$ and $F_{3} 18 \mathrm{~cm}$. It is true there are striking peaks in the curve at $138 \mathrm{~cm}$ and $115 \mathrm{~cm}$, but these are based on one spectrum, at least the one at $138 \mathrm{~cm}$, while the one at $115 \mathrm{~cm}$ may perhaps be reckoned under one maximum together with $F_{2}$. It is also striking, that no or only a single Carpinus pollengrain is present at $\mathbf{F}_{1}, \mathbf{F}_{\mathbf{2}}$ shows a continuous Carpinus curve, while $\mathbf{F}_{\mathbf{3}}$ clearly has a Carpinus maximum. Persch (1950) and Slotboom (1963) also notice this. The Aamsveen shows this picture too. 


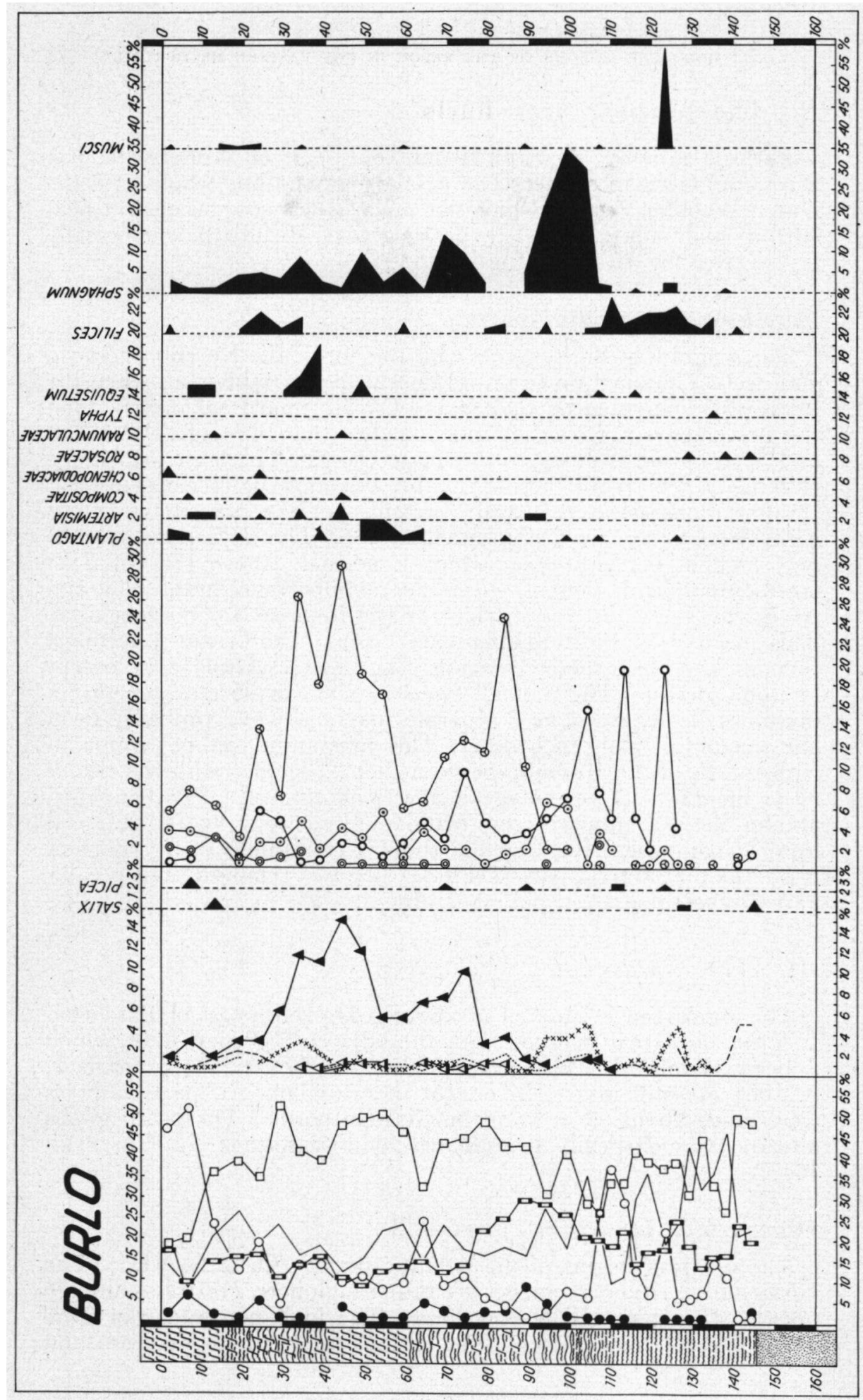




\section{The peatbog near Burlo}

Burlo is situated at about $10 \mathrm{~km}$ south-east of Winterswijk, just across the German border. The peatbog formed one whole with the Dutch Wooldse Veen of which not much is left now because of peat cutting and cultivation. The peatbog was already palynologically investigated by $\mathrm{H}$. КосH in 1930 .

\section{Palynological investigation (diagram 2)}

The diagram of Burlo agrees with the one of the Korenburgerveen very well. The diagram begins $(145 \mathrm{~cm}$ ) in the Subboreal, when the forest was dominated by Quercus and Corylus (mixed oakforests). First the percentage of Quercus is much higher than that of Corylus, but at $100 \mathrm{~m}$ Corylus is going to dominate Quercus. The high percentage of Betula is remarkable here. Probably this must be ascribed to local circumstances. Fagus is already present, but the percentage is not high. Fraxinus reaches a percentage of $5 \%$. The Tilia percentage is only high in the beginning, which is normal. Above $130 \mathrm{~cm}$ Tilia is only sporadically present. Ulmus is of no importance in this diagram. At $75 \mathrm{~cm}$ Corylus decreases sharply, Fagus increases for the first time. This means that the Subatlanticum begins. The Corylus percentage remains low, Alnus increases again. Fagus increases till $15 \%$, except for some decline. The 2 small Fagus maxima at $75 \mathrm{~cm}$ and $45 \mathrm{~cm}$ must not be regarded as 2 separate maxima. They probably form one maximum with each other. This maximum can be compared with the $F_{1}$ of the Korenburgerveen then. Together with the rise of Fagus the Ericaceae percentage increases enormously. This happened also in the Korenburgerveen. Human influence is to be observed from $70 \mathrm{~cm}$, where the Cerealia show a continuous curve. Further it is clear that a great part of this peatbog was removed. The greater part of the subatlantic period is absent.

\section{The Aamsveen}

The Aamsveen is situated at about $5 \mathrm{~km}$ south-east of Enschede. It forms one great peatbog with the adjacent German part, which is being reclaimed. This does not alter the fact that large parts of peatbog are still intact. In one of these undamaged parts samples were taken about $50 \mathrm{~m}$ from the German border. The peatbog was already palynologically investigated by FLORSGHütz (in Hyszzeler 1947).

\section{Pollenanalytical investigation (diagram 3).}

The diagram begins in the Atlantic period (O. \& S. VIII). The Ulmus and Quercus percentages are rather high here. Fraxinus is already present. Corylus dominates the forest. The high percentage of Tilia is remarkable here. When Tilia and Ulmus begin to decrease and 
Corylus has had its last maximum $(300 \mathrm{~cm})$, the Subboreal begins (IX). Here the Corylus curve decreases gradually while Alnus reaches higher values. Fagus appears too. Towards the end of the Subboreal Fagus shows a continuous curve (from $245 \mathrm{~cm}$ ). At $\pm 205 \mathrm{~cm}$ Corylus decreases definitely. At the same time Fagus increases. This means that the subatlantic period $(\mathrm{X})$ begins here.

\section{Fagus}

In this diagram too, the Fagus curve does not go gradually to its highest maximum at $33 \mathrm{~cm}$. Just like in the Korenburgerveen we clearly distinguish some maxima. $F_{1}$ at $200 \mathrm{~cm}, F_{2}$ at $105 \mathrm{~cm}, F_{3}$ at $75 \mathrm{~cm}$ and $F_{4}$ at $33 \mathrm{~cm}$. In this peatbog also there is no Carpinus at $F_{1}, F_{2}$ shows a continuous Carpinus curve and $F_{3}$ has a Carpinus maximum in addition. At the last Fagus maximum Carpinus decreases.

\section{Discussion}

When studying pollendiagrams it is important to observe, according to FirBas (1949), that the number of pollen grains of Fagus is generally comparatively smaller than the number of pollen grains of most other trees. This on account of the following reasons:

1. A flowering beech produces a relatively small number of pollengrains.

2. The number of years in which a beech blooms is few.

3. The pollen of the beech is not so much represented in the higher layers of air, because the greater part of it sinks on the spot.

All the three peatbogs, which were investigated, show high percentages of Fagus. The maxima amount to: the Korenburgerveen $25 \%$, the Burlo peatbog $15 \%$ and the Aamsveen even $35 \%$. This indicates that this part of the eastern Netherlands was covered with extensive beech forests during a part of the subatlantic period. This is also evident from diagrams of TEN HouTEN (1935) and FLORSCHÜTZ (1944). Not published diagrams of the Haaksbergerveen (OVER) and Vragenderveen also show high percentages of Fagus: $43 \%$ and 32,5\% respectively. Further the Korenburgerveen and the Aamsveen show clearly how the percentage of Fagus increases, after the beginning of the Subatlantic period, to a maximum, that must be in the beginning of our era (Jonker, 1963). After that the Fagus percentage decreases a few percents, where upon a second maximum arises and so on. In that way 3 Fagus maxima can be distinguished in the Korenburgerveen and even 4 in the Aamsveen. Persch (1950) also distinguished 4 maxima in a diagram of the Hohe Venn, just like SLotвoom, who investigated some peatbogs in Luxemburg and a "vivier" in the Hohe Venn (1963). Overbeck and SchnerDer (1938) also found 4 Fagus peaks in Germany. Janssen (1960) found 2 Fagus maxima in Southern Limburg, just like Hummed (1949) in the Eiffel. Janssen 
supposes that $F_{3}$ and $F_{4}$ are absent. How can we explain this conduct of the Fagus curve?

In the diagrams of the Aamsveen, Haaksbergerveen, Vragenderveen and more or less in the Korenburgerveen, the course of the Alnus curve is remarkable. It is striking, especially in the Aamsveen, that where Fagus has a maximum, Alnus shows a minimum and the reverse. Perhaps this is accidental, for it.is normal, that when the percentage of one tree species increases, this must be at the cost of other species. But here it is only Alnus that decreases when Fagus increases. The percentages of the other trees do not changé. Some trees, like Quercus, even increase. If Alnus should be left out of the treepollen sum a continuously increasing Fagus curve. with only one peak will arise. The question is, however, if Alnus may be removed from the treepollen sum (JANSSEN, 1959), because here is no local occurrence of Alnus. In the environment Alnus is present too. In diagrams of peatbogs in a hilly district, in which Alnus is not present, except in the bog itself, a wrong picture can certainly arise and then it is advisable to leave Alnus out of the treepollen sum. So if we accept that in this case Alnus is no "disturbing factor", what can the explanation of the Fagus maxima be?

Some investigators are inclined to ascribe the various maxima and minima to human influence. If this supposition is correct, man would have intervened in Germany, the Netherlands, Belgium as well as in Luxemburg in the same way, so that the same picture arose. This is not probable. In the Aamsveen a continuous curve of the Cerealia begins only between $F_{3}$ and $F_{4}$, while only after $F_{4}$ buman influence becomes more clear, witness the remnants of a peatbog-fire at $13 \mathrm{~cm}$, together with $14 \%$ Fagopyrum and high percentages of Rumex $(40 \%)$. In the Korenburgerveen the Cerealia already show a continuous curve before the third Fagus maximum is reached. Persch (1950) and Slotboom (1963) too found a continuous Cerealia curve during $\mathbf{F}_{\mathbf{8}}$. Overbeck and Schneider (1938) already found Cerealia pollengrains after $F_{2}$. JANSSEN (1960) supposes that the lack of $F_{3}$ and $F_{4}$ in South-Limburg and in the Eiffel is on account of man. It is not probable and certainly not in the Korenburgerveen and the Aamsveen, that the Fagus maxima and minima must be ascribed to human influence. The diagrams of these peatbogs do not point to that direction.

JANSSEN (1960) also gives the natural life time of a beech forest as one of the possible causes of the maxima and minima.

Another explanation for the development of the 4 Fagus peaks Srotвoom (1963) suggests. His pollendiagram of the peatbog of the Birkbach (Luxemburg) can be compared with Persch's diagram of Neu-Hattlich in the Hohe Venn (1950) on many points. Both the diagrams show 4 Fagus maxima, the first maximum of which has the highest percentage of Fagus $\left( \pm 60 \%\right.$, while at $\mathbf{F}_{2}, \mathbf{F}_{3}$ and $\mathbf{F}_{4}$ the percentage gradually decreases. Also the behaviour of Carpinus, Tilia and the appearance of Cerealia is in both cases all but the same. Persch arrives with the help of $\mathrm{C} 14$ datings of some comparable 
diagrams in the Eiffel and the Rhön, at the following absolute datings:

$$
\begin{array}{ll}
F_{1}=\text { about the beginning of our era } & F_{3}=\text { C. } 1200 \text { A.D. } \\
F_{2}=\text { C. } 700 \text { A.D. } & F_{4}=\text { C. } 1600 \text { A.D. }
\end{array}
$$

The striking thing is, according to SLотвоом, that the Fagus maxima always fall between the transgression phases, which BAKKER, Bennema, and others distinguish in the Dutch coastal region. Slotвоом (1963) says: "It is plausible that there is a connection between these two phenomena, the four peaks of Fagus occurring in a large area". During the regression phases the climate would be more continental, which would benefit the beech. Even now Fagus still has its largest range in continental Central-Europe. In the Netherlands too, high percentages of beech are to be found where, in comparison with the rest of the Netherlands, the conditions are more continental, namely in Southern Limburg (calcareous district and loess district), and the Achterhoek and Southern Twente (subcentreuropean district).

So the beech would be at a disadvantage particularly in the extreme oceanic areas, like the west of the Netherlands. This idea seems to be in conflict with the opinion defended a.o. by VAN ZEIST (1959), that the spreading of the beech is connected with the increase of oceanic conditions.

The question remains, however, to what extent the Fagus peaks are synchronous in the Netherlands, Belgium, Luxemburg and Germany. Therefore it will be advisable always to perform accurate C-14 datingtests in further investigations.

In the pollendiagrams the usual peat- and pollen symbols are used (see also Janssen, 1960, p. 113). The first of the three subdiagrams of the composite type contains the percentages of Alnus, Betula, Corylus, Pinus and Quercus. In the second one the percentages of Carpinus, Fagus, Fraxinus, Tilia and Ulmus are given and in the third one those of Cyperaciae, Gramineae, Ericaceae and Cerealia.

The examination of the peatsamples took place in the Institute of Systematic Botany at Utrecht under the supervision of professor Dr. F. P. Jonker, to whom we are very grateful for his help.

\section{REFERENCES}

AdRIANI, M. 1937. Synökologische Beiträge zur Frage der Bedeutung von Fagus silvatica in einigen niederländischen Waldassoziationen. Mitteilungen der Floristisch-soziologischen Arbeitsgemeinschaft in Niedersachsen, Hannover. He. 3: 185-192.

Beijerinck, W. 1934. Sphagnum en Sphagnetum. Amsterdam.

. 1937. Zadenatlas der Nederlandse flora. Wageningen.

Dremont, W. 1938. Zur Soziologie und Synoekologie der Buchen- und Buchenmischwälder der nordwestdeutschen Mittelgebirge. Mitteilungen der Floristisch-soziologischen Arbeitsgemeinschaft in Niedersachsen, Hannover He. 4: 1-182.

DoING, H. 1962. Systematische Ordnung und floristische Zusammensetzung niederländischer Wald- und Gebuischgesellschaften. Wentia 8: 1-85 and Thesis Wageningen.

Erotman, G. 1943. An introduction to Pollenanalysis. Waltham (Mass.). 
Fargri; K. 1954. On Age and Origin of the beech forest (Fagus silvatica L.) at Lygrefjorden, near Bergen (Norway). Danmarks Geologiske Undersøgelse. II. Raekke. nr. 80. Copenhagen.

and J. Iversen. 1950. Textbook of modern pollenanalysis. Copenhagen.

FIRBAs, F. 1949 and 1952. Spät- und nacheiszeitliche Waldgeschichte Mitteleuropas nördlich der Alpen. Bd. I and II. Jena.

Houten, J. TEN. 1935. Untersuchungen an niederländischen Mooren-K. Korenburgerveen. Recueil des Trav. Bot. Néerlandais 32: 430-437. Also published as Meded. v. h. Bot. Mus. en Herb. Utrecht nr. 23.

Vorming en vegetatie van het Korenburgerveen. Jaarboek van de Vereniging tot Behoud van Natuurmonumenten in Nederland. 1929$1935,200-208$.

Hijszeler, C. 1947. Een nederzetting bij Losser (Palynology by F. Florschütz, o.a. of Aamsveen): Verslagen en mededelingen van de Vereniging tot Beoefening van Overijsselsch Regt en Geschiedenis. 6le stuk - 2e reeks 37e stuk: $1-17$.

JANssen, C. R. 1959. Alnus as a disturbing factor in pollen diagrams. Acta Botanica Neerlandica, 8: 55-58. Also published as Meded. v. h. Bot. Mus. en Herb. Utrecht nr. 153.

1960. On the late-glacial and post-glacial vegetation of South Limburg (Netherlands). Wentia 4 and Thesis Utrecht. Also published as Meded. v. h. Bot. Mus. en Herb. Utrecht nr. 168.

Jeswiet, J., W. C. DE LeEUW and R. TüxEN. 1933. Uber Waldgesellschaften und Bodenprofile. Ned. Kruidk. Archief 43: 293-333.

Jonker, F. P. 1963. De Geschiedenis van de Beuk in West-Europa. Vakblad voor Biologen 43, nr. 11: 173-181.

Косн, Н. 1930. Paläobotanische Untersuchungen einiger Moore Münsterlandes. Beihefte zum Botanischen Centralblatt 46 II: $1-70$.

Mrkxelsen, V. M. 1963. Beech as a Natural Forest Tree in Bornholm. Botanisk Tidsskrift 58: 253-280.

Over, H. J. 1957. Een pollenanalytisch onderzoek van het Haaksbergerveen. mss. Utrecht.

Rubner, K. 1934. Die Pflanzengeografische-ökologischen Grundlagen des Waldbaus, 3e Aufl., Neudamm.

Sissingh, G., J. VIIEGER and V. WESTHOFr. 1940. Enkele aanteekeningen omtrent de plantenassociaties in de omgeving van Winterswijk. Ned. Kruidkundig Archief 50: 58-66.

SLotвoom, R. T. 1963. Comparative geomorphological and palynological investigation of the Pingos (Viviers) in the Hautes Fagnes (Belgium) and the Mardellen in the Gutland (Luxemburg). Zeitschrift für Geomorphologie N.F. 1963, and Thesis Amsterdam: 1-41.

Scharfetter, R. 1929. Projektions-Atlas, He. I. Die Verbreitung europäischer Waldpflanzen.

Straka, H. 1957. Pollenanalyse und Vegetationsgeschichte. Die Neue BrehmBücherei, He. 202.

Westhoff, V., J. Dijk, H. Passchier and G. Sissingh. 1946. Overzicht der plantengemeenschappen in Nederland, 2nd Ed. Bibliotheek Ned. Nat. Hist. Ver. nr. 7, Amsterdam.

Zeist, W. van. 1955. Pollenanalytical investigations in the northern Netherlands. Acta Botanica Neerlandica, 4: 1-81 and Thesis Utrecht. Also published as Meded. v. h. Bot. Mus. en Herb. Utrecht nr. 127. 1959. Studies on the Post-Boreal vegetational history of South-Eastern Drenthe (Netherlands). Acta Botanica Neerlandica 8: 156-184. 


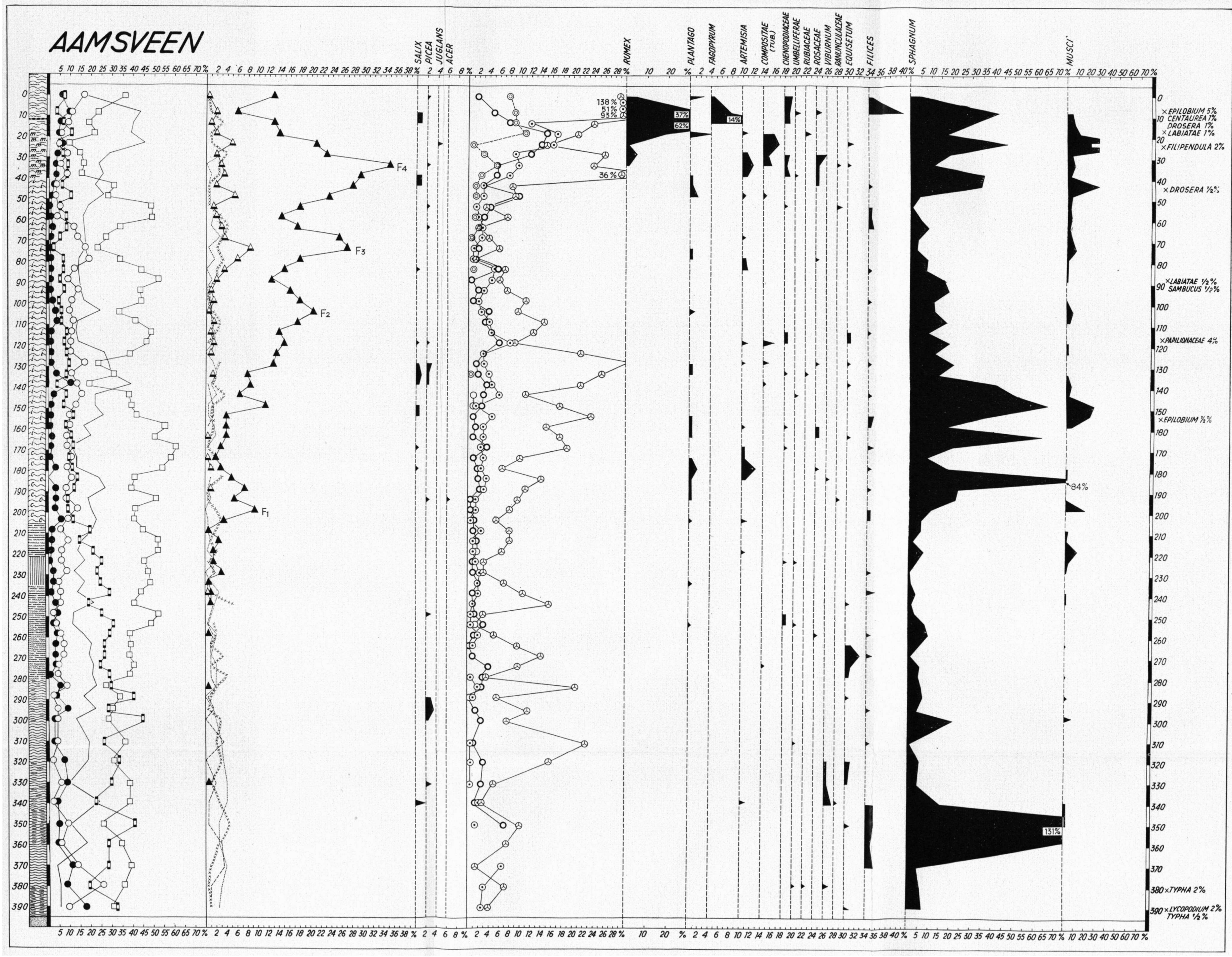




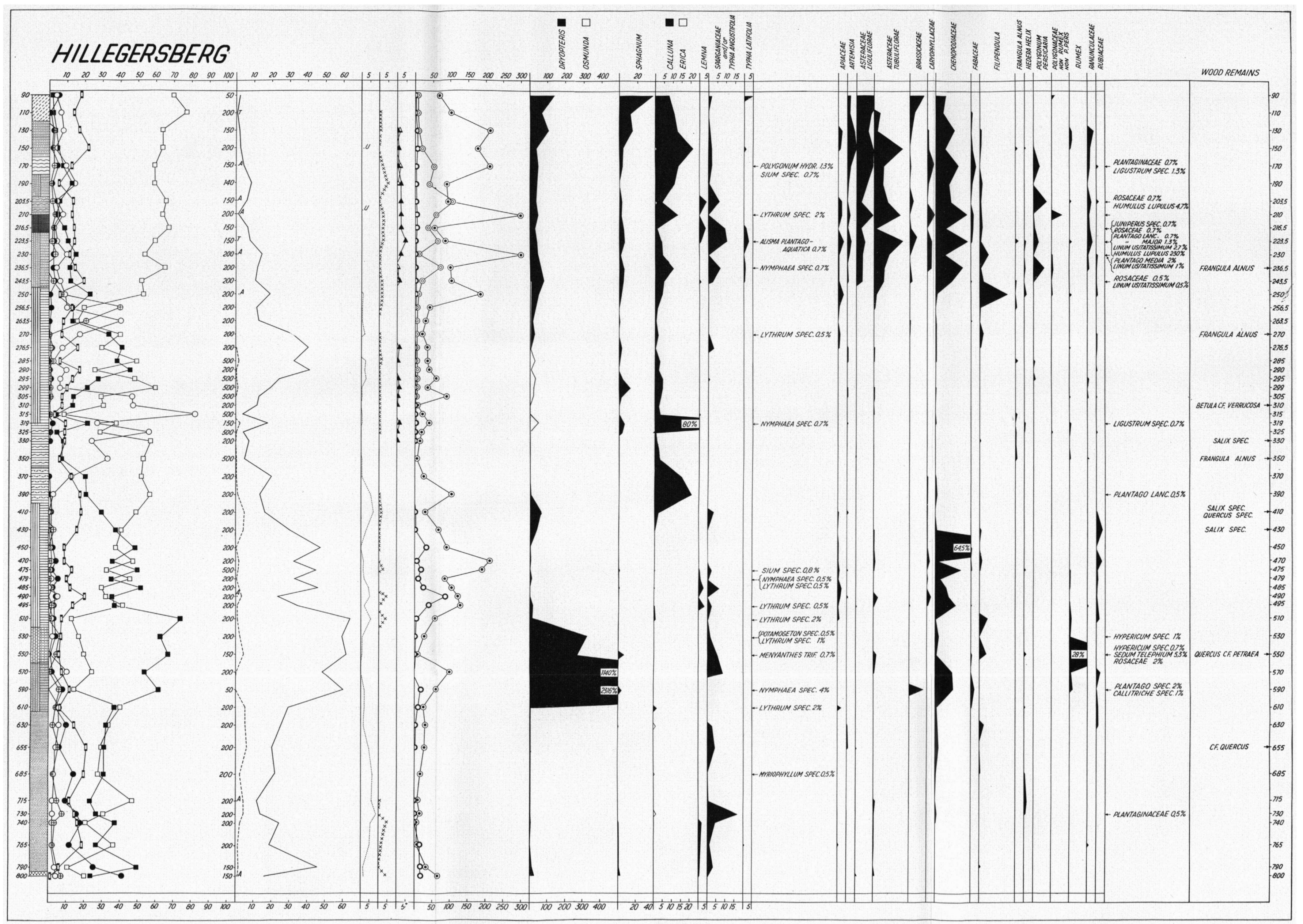




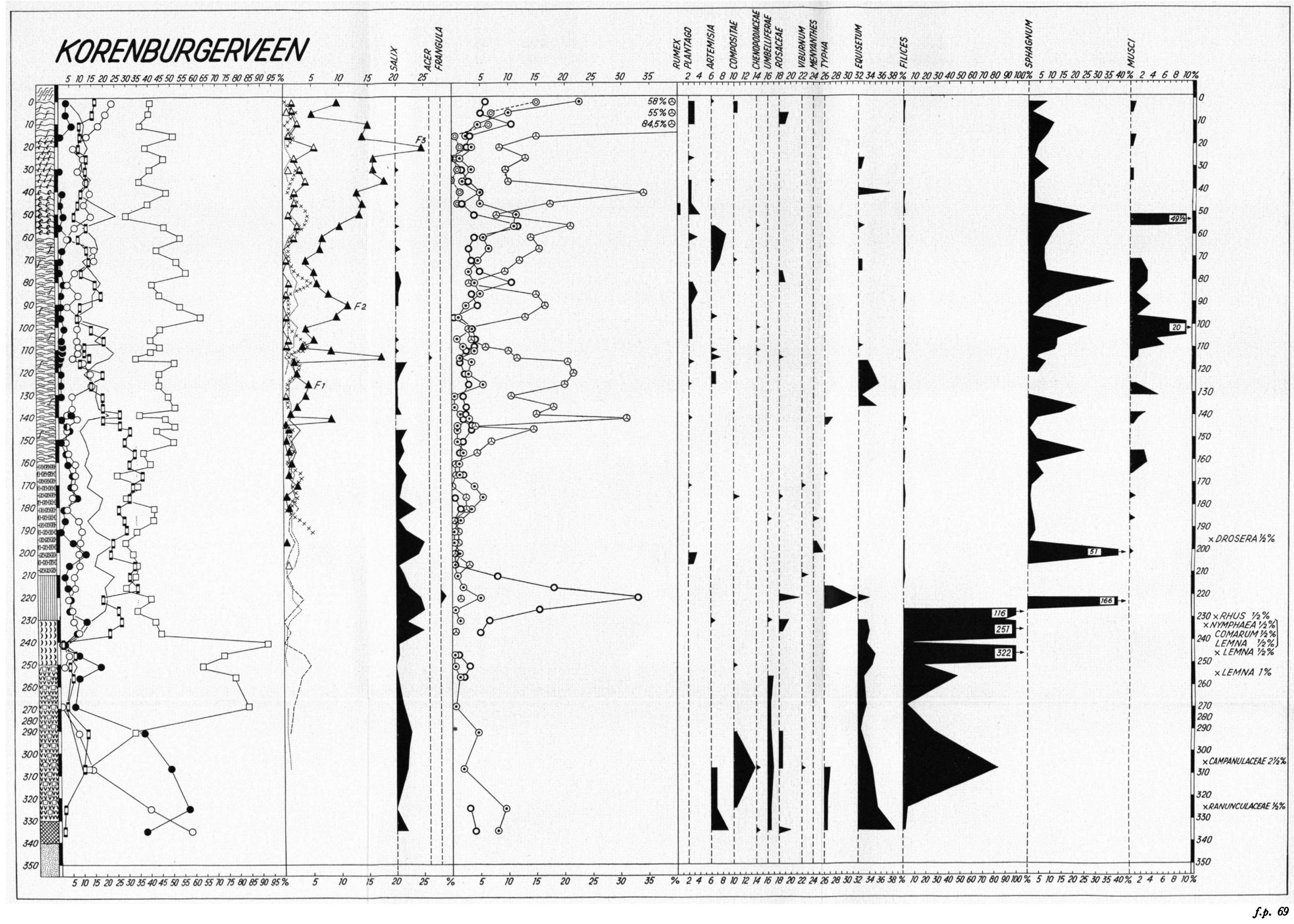

